УДК 364-7

Н. І. Кривоконь, д. психол. н., профресор

\title{
ДЕФІНІЦІЯ КАТЕГОРІЇ «СОЦІАЛЬНІ ПОСЛУГИ»: ПРОБЛЕМИ КОНЦЕПТУАЛІЗАЦІЇ
}

Актуальність теми дослідження. Цього року Верховна Рада України ухвалила новий Закон «Про соціальні послуги», котрий передбачає чимало нововведень. Даний факт визначає актуальність концептуалізації соціальних послуги, що дозволить не лише поглибити розуміння тих реформаторських процесів, які відбуваються на разі в державі, але й спрогнозувати їх подальще спрямування, перспективи та наслідки (ефекти).

Постановка проблеми. Не дивлячись на те, що соціальні послуги є невід'ємним атрибутом соціальної держави, єдиного наукового підходу стосовно їх визначення, змісту, структури, характеристик та класифрікації поки що не розроблено. Відсутність чітких обгрунтованих позицій стосовно закономірностей формування соціальних послуг як відображення взаємовідносин держави та суспільства ускладнює чітке системне бачення їх сутності і зумовлює необхідність постійного наукового пошуку в даній царині.

Аналіз останніх досліджень і публікацій. Більшість авторів, предметом досліджень яких виступають соціальні послуги, спираються на теоретичні концепції сервісної економіки, теорії соціального та державного управління, маркетингу та управління послугами, соціального права, теорій соціальної роботи. У статті стисло аналізуються доробки зарубіжних авторів (N. Lunt, F. Mitchell, I. Shaw, A. Lara Montero), котрі здійснювали дослідження особливостей фрункціонування сфрери соціальних послуг переважно у Європейських країнах, а також вітчизняних науковців і практиків, хто зробив свій внесок у розвиток наукових уявлень про соціальні послуги (В. Апопій, Н. Кабеченко, Л. Сідєльнік та ін.)

Виділення недосліджених частин загальної проблеми. Не зважаючи на значний інтерес до проблематики соціальних послуг, переважна більшість дослідників характеризують їх у міждисциплінарних векторах. Натомість концептуальні засади соціальних послуд в аспекті теорії соціальної роботи розроблені недостатньо.

Постановка завдання. Дослідження має на меті представити міркування щодо концептуалізації соціальних послуг в Україні з позицій соціальної роботи.

Виклад основного матеріалу. У статті подано аналіз існуючих підходів щодо дефрініції «соціальні послуги». Представлено фрокуси аналізу категорії соціальних послуг, запропоновано визначення. Акцентується увага на значимості розуміння соціальних послуг в контексті процесу (діяльності) та результату (ефекту). Підкреслено необхідність розвитку системи вимірювання послуг і наснаження клієнтів.

Висновки. Основні проблеми концептуалізації соціальних послуг зумовлені багатоаспектністю їх розуміння та використання. Позаяк головним об'єктом (отримувачем) соціальних послуг виступає людина, наділена суб'єктністю, послуга має розалядатися як процес і результат соціальної взаємодії.

Ключові слова: теорія соціальної роботи; соціальні послуги; концептуалізація соціальних послуг.

N. I. Kryvokon, Doctor of Psychology, Professor

\section{DEFINITION "SOCIAL SERVICES": PROBLEMS OF CONCEPTUALIZATION}

Urgency of the research. Verkhovna Rada of Ukraine adopted a new Law "On Social Services" this year that provides a number of innovations. This fact determines the relevance of the conceptualization of the definition of "social services", which will allow not only to deepen the understanding of those reform processes that are taking place now, but also to predict their further direction, prospects and consequences (effects).

Target setting. Despite the fact that social services are an inalienable attribute of a social state, the one scientific approach to their definition, content, structure, characteristics and classification has not yet 
been developed. The absence of clear, well-founded positions regarding the patterns of the social services formation as a reflection of relationship between the state and society complicates the clear systemic vision of their essence and predetermines the need for constant scientific research in this domain.

Actual scientific researches and issues analysis. Most authors whose subject of research are social services are based on the theoretical concepts of service economics, the theory of social and public administration, marketing and management of services, social law and theories of social work. The article briefly reviews the work of foreign authors (N. Lunt, F. Mitchell, I. Shaw, A. Lara Montero) who carried out the study of the features of the functioning of the social services sector mainly in European countries as well as domestic scholars and practitioners who had contributed to the development of scientific ideas about social services (V. Apopiy, N. Kabechenko, L. Sidelnik, etc.).

Uninvestigated parts of general matters defining. Despite considerable interest in the issue of social services, the overwhelming majority of researchers characterize them in an interdisciplinary vector. Instead, the conceptual foundations of social services in the context of the theory of social work are not sufficiently developed.

The research objective. The aim of the study is to provide an overview of the conceptualization of social services in Ukraine from the point of view of social work.

The statement of basic materials. The article analyzes the existing approaches to the definition and characteristics of the definition of "social services". The features of social services, their structural components are presented. The emphasis is on the importance of understanding social services in the context of the process (activity) and the result (effect). The necessity of development of the system of measuring services and attracting clients is emphasized.

Conclusions. Their multidimensionality of their understanding and implementation predetermines the main problems of social services conceptualization. Since the main object (recipient) of social services is a person endowed with subjectivity the service should be regarded as a process and the result of social interaction.

Keywords: theory of social work; social services; conceptualization of social services.

DOI: 10.25140/2412-1185-2019-1(13)-37-45

Актуальність теми дослідження. У січні 2019 року Верховна Рада України ухвалила Закон «Про соціальні послуги» (№ 2671-VIII) [1], котрий у квітні був підписаний Президентом. Закон набуває чинності 31 січня 2020 р. Відтак, в Україні вводяться нові організаційні та правові засади надання соціальних послуг, спрямованих на профрілактику, подолання складних життєвих обставин та/або мінімізацію їх наслідків, особам/сім'ям, які перебувають у складних життєвих обставинах.

Документ передбачає чимало нововведень, зокрема, формулюються нові терміни; визначено систему надання соціальних послуг, котра складається із сукупності суб'єктів, що формують державну політику з питань надання соціальних послуг; представлено стислу класифрікацію соціальних послуг; запропоновано новий підхід до оцінювання потреб особи у соціальних послугах; змінено умови надання послуг; запроваджується реєстр надавачів та отримувачів соціальних послуг та ін. I хоча, успішна реалізація Закону ще потребує розробки та створення цілої низки підзаконних актів і проведення інших важливих нормативних процедур, сам фракт рефрормування існуючої системи надання соціальних послуг в державі сприймається нами як дуже значущий та позитивний.

Зважаючи на новітні запити та тенденції в контексті розвитку соціальної сфери держави взагалі, та системи соціальних послуг зокрема, досить актуальною проблематикою, як в теоретичному, так і практичному аспектах, уявляється визначення та концептуалізація самої категорії «соціальні послуги». Дані наукові розвідки дозволять не лише поглибити розуміння тих рефрорматорських процесів, які відбуваються на разі в державі, але й певним чином спрогнозувати їх подальше спрямування, перспективи та наслідки (ефекти), а також встановити можливі проблемні питання чи ризики.

Постановка проблеми. Не дивлячись на те, що соціальні послуги є важливим і невід'ємним атрибутом соціальної держави, єдиного відпрацьованого наукового підходу стосовно їх визначення, змісту, структури, характеристик та класифрікації поки що не розроблено. Це передусім пояснюється багатопредметними аспектами розгляду дефініції «соціальні послуги»: її 
аналізом активно займаються економісти, соціологи, правознавці, фахівці із соціальної роботи, державного управління, менеджменту тощо. 3 іншого боку, розвиткові даної проблематики перешкоджає недостатня наукова розробка цілої низки тих наукових позицій, котрі виступають більш загальними по відношенню до категорії «соціальні послуги». Приміром, можна стверджувати про неузгодженість і розмитість поглядів щодо розуміння категорій «соціальна держава», «соціальна сфера», «соціальний захист», «соціальний капітал», «якість життя» тощо.

Важливими чинниками, що також зумовлюють труднощі інтерпретації та концептуалізації категорії «соціальні послуги», виступають зміни, котрі притаманні будь-якому суспільству, і ті потреби людей, які вони актуалізують. Йдеться про те, що система соціальних послуг, як спосіб реагування на суспільні запити, повинна постійно перебувати у стані перманентного розвитку, щоб відповідати нагальним потребам суспільства. А це, в свою чергу, вимагає постійної еволюції наукових поглядів і уявлень, здійснення відповідних досліджень з урахуванням найсучасніших тенденцій та інновацій, побудови нових моделей тощо. Причому, це стосується як системи соціальних послуг в інституційному контексті, так і в понятійно-термінологічному сенсі. Відтак, відсутність чітких обґрунтованих позицій стосовно закономірностей формування соціальних послуг як відображення взаємовідносин держави та суспільства ускладнює чітке системне бачення їх ґенези та сутності, і, як наслідок, зумовлює необхідність постійного наукового пошуку в даній царині.

Аналіз останніх досліджень і публікацій. Більшість авторів, предметом дослідження яких виступають соціальні послуги, спираються на теоретичні концепції сервісної економіки, теорії соціального та державного управління, маркетингу та управління послугами, соціального права, і, звичайно, теорій і методів соціальної роботи.

Найбільш відомими концептуальними доробками стосовно різних соціально-економічних, управлінських і маркетингових аспектів послуг є роботи G. Lynn Shostack, в яких було визначено, що послуга, як і будь-який інший продукт, може бути об'єктом купівлі-продажу, купується на основі вільного вибору, має споживчу вартість, що підтверджує її товарну сутність, невіддільність від категорії товару. Основні характеристики послуг: невідчутність (нематеріальний характер), невіддільність споживання і виробництва, неоднорідність (змінюваність), нездатність до зберігання [2]. Щодо соціальних послуг, то автори T. Rieder, A. Schott-Winterer, A. Woller визначають їх як «такі, що надаються професійно, засоби для поліпшення, підтримки та відновлення фрізичного, психологічного, соціального та культурного функціонування окремих осіб або груп людей, а також для соціальної та культурної самобутності суспільства» [3, с. 300]. В працях інших авторів [4; 5; 6] наголошується, що сфера послуг виступає однією з найперспективніших та найдинамічніших галузей сучасної економіки, якій притаманні складні системи взаємозв'язків. Ця сорера є рушієм становлення інформаційно-сервісного суспільства.

Ретельний огляд наукового доробку у сфері соціальних послуг у Великій Британії та Австралії було здійснено N. Lunt, F. Mitchell, I. Shaw, котрі систематизували досвід досліджень в системі соціального сервісу і послуг (Social Services) в період з 2005 - 2012 рр. [4]. Автори дійшли висновку про недостатність практично орієнтованих пошукань у царині теорії, організації та надання соціальних послуг і необхідності активізації цієї роботи. Актуальні принципи, визначення та особливості соціальних послуг на різних рівнях в Данії та Нідерландах представлено в роботі A. Lara Montero [5], де автор концептуалізує соціальні послуги в контексті кейс-менеджменту. Внесок у дослідження різних видів і аспектів соціальних послуг здійснили й інші зарубіжні вчені, зокрема: E. Coren, M. Fisher, C. Freedman, L. Joubert, S. Kruppa, N. Russell, Л. Кухтінова, Р. Мірзандаєва, О. Холостова та ін.

Останнім часом проблематика соціальних послуг стала предметом пильної уваги і багатьох вітчизняних дослідників, серед яких: В. Апопій, Т. Артюх, Ю. Коваленко, І. Олексин, С. Попова, А. Румянцева, Н. Шутовська, Т. Футало та ін. Ідеї щодо вдосконалення системи надання соціальних послуг викладено у працях В. Андріїва, В. Бабаєва, Н. Борецької, О. Давидюк, В. Єлагіна, Б. Сташківа, Т. Поспєлової, Л. Сідєльнік та ін. Активно аналізують сучасний стан розвитку системи надання соціальних послуг та управління нею науковці: О. Берданова, І. Гнибіденко, В. Гошовська, К. Дубич, Л. Ільчук, Е. Лібанова, К. Міщенко, В. Скуратівський та ін. Інноваційні моделі соціальних послуг для вразливих груп населення представлені та детально проаналізовані у збірках за результатами проектів Українського фонду соціальних інвестицій [7]. Ми також неодноразово зверталися до тематики соціальних послуг, зокрема їх розуміння у 
міждисциплінарному контексті, а також з точки зору соціально-психологічного аналізу надання соціальних послуг як професійної діяльності та особливостей соціально-психологічного забезпечення їх розвитку [8].

Виділення недосліджених частин загальної проблеми. Однак, не зважаючи на значний інтерес до проблематики соціальних послуг та соціального обслуговування (в Україні останній термін найчастіше вживається в межах системи соціального захисту населення), переважна більшість дослідників характеризують їх окремо в економічному, правовому, соціальнопсихологічному та управлінському аспектах. Натомість концептуальні засади соціальних послуг в контексті теорії та методів соціальної роботи розроблені недостатньо. Крім того, як вже зазначалося вище, в умовах постійних суспільних трансформацій відбувається вдосконалення й розвиток як самих соціальних послуг, так і наукових уявлень про їх компонентну структуру, принципи, види, особливості та результати впровадження. Усе вищезазначене пояснює наш інтерес до означеної вище дефініції та прагнення розширити межі її сприйняття та розуміння.

Постановка завдання. Дослідження має на меті представити міркування щодо проблем концептуалізації соціальних послуг в Україні з позицій соціальної роботи.

Виклад основного матеріалу. Упродовж останніх десятиліть відбулася певна еволюція науково-практичних уявлень про соціальне обслуговування та соціальні послуги.

Перш за все варто відмітити, що у світовій літературі переважно вживається термін «соціальні послуги», тоді як термін «соціальне обслуговування» майже не зустрічається (крім російськомовних видань). У вітчизняному дискурсі існують доробки, де дається аналіз (в соціологічному, правовому й управлінському аспектах) поняття «соціальне обслуговування». Наприклад, у статті [9] наведено результати дослідження соціального обслуговування на основі методології соціологічного аналізу. Це дозволило автору розглядати його як соціальний інститут і трактувати в широкому і вузькому розумінні: «У широкому сенсі соціальне обслуговування постає як організована соціальна взаємодія між різними соціальними інститутами, включаючи державу і громадянське суспільство, між різними соціальними групами і індивідами, які в ході соціальної діяльності вирішують життєво важливі проблеми як для тих, хто знаходиться у важкій життєвій ситуації, так і для тих, хто має в своєму розпорядженні можливості надання їм соціальних послуг і допомоги. У вузькому сенсі соціальне обслуговування розуміється як технології роботи, сукупність прийомів, методів і дій організацій, фахівців, спрямованих на надання допомоги громадянам, що знаходяться у важкій життєвій ситуації, не здатних до самообслуговування і таким, що потребують постійного догляду» [9, с. 73]. В багатьох інших роботах термін «соціальне обслуговування» вживається як синонімічний до «соціальні послуги», або ж для підкреслення процесного аспекту надання соціальних послуг в системі соціальної роботи.

Ми дотримуємося думки, що використання терміну «соціальне обслуговування»є виявом певної інерції у понятійно-категоріальному апараті соціальної роботи, данина термінології колишньої радянської «системи соціального забезпечення», де «соціальне обслуговування» вважалося ії складовою. На разі, коли Україна розвивається в умовах ринкової економіки, більш сучасним, адекватним соціальним реаліям терміном є «соціальні послуги», а «соціальне обслуговування» має трактуватися у вузькому розумінні як «процес надання соціальних послуг».

Стосовно визначення категорії «соціальні послуги» також немає одностайності та усталеності. У найбільш загальному вигляді соціальні послуги розглядаються як такий атрибут життєдіяльності людини, котрому притаманні специфічні властивості, серед яких найчастіше згадуються наступні: 1) соціальні послуги з'являються тоді, коли є необхідність задоволення потреб людини; 2) головним об'єктом виступає особистість, наділена не лише потребами, але і власною суб'єктністю; 3) існує адресна суб'єктивна направленість послуг; 4) послуга є результатом соціальної взаємодії споживача та виробника, що виявляється у суб’єктивному відчутті їх задоволення/незадоволення. Також серед характеристик соціальних послуг не можна не відмітити й те, що в ході надання соціальна послуга використовується повністю, її не можна відкласти про запас, використати вдруге; кожна послуга є унікальною, вона не може повторюватися однаково, бути якісно однорідною; надання та споживання послуги відбуваються одночасно, нероздільно та ін.

Визначення та використання терміну «соціальні послуги» на разі також зазнало певних змін. Приміром, у двох редакціях Закону України «Про соціальні послуги» (2003 р. та 2019 р.) наводяться такі, що суттєво відрізняються одне від одного підходи до трактування дефініції «соціальні послуги». Так, у Законі 2003 року під соціальними послугами розуміється «комплекс правових, 
економічних, психологічних, освітніх, медичних, реабілітаційних та інших заходів, спрямованих на окремі соціальні групи чи індивідів, які перебувають у складних життєвих обставинах та потребують сторонньої допомоги, з метою поліпшення або відтворення їх життєдіяльності, соціальної адаптації та повернення до повноцінного життя» (ст. 1, абз. 2). У відповідному Законі редакції 2019 року (ст. 1, п. 17) вказано, що «соціальні послуги - дії, спрямовані на профрілактику складних життєвих обставин, подолання таких обставин або мінімізацію їх негативних наслідків для осіб/сімей, які в них перебувають» [1]. Як бачимо, друге визначення більш конкретизоване і чітке, хоча в обох випадках воно пов'язане із терміном «складні життєві обставини».

Зазначимо, що і в науковій літературі різного спрямування також помітні певні тенденції стосовно зміни уявлень про соціальні послуги. На наш погляд, відбувається пошук теоретикометодологічних і прикладних різнопредметних підходів, котрі уможливлюють осучаснення, концептуалізацію та систематизацію поглядів на дану категорію. Відтак, хочемо висловити і власну позицію стосовно даної проблематики, напрацьовану завдяки теоретичним науковим розвідкам, аналізу низки доступних вітчизняних і зарубіжних джерел та набутого практичного досвіду в царині розвитку та запровадження інноваційних соціальних послуг в Україні.

Отже, при визначенні категорії «соціальні послуги» ми пропонуємо брати до уваги наступні положення, котрі демонструють різноманітні аспекти її розгляду, - з одного боку. А з іншого, фокусують увагу на їх важливих особливостях і характеристиках.

1. Соціальні послуги як продукт соціально корисної діяльності, суспільне благо.

Даний аспект зосереджує увагу на суспільній значимості соціальних послуг. Відтак, сутність соціальних послуг визначається виходячи з їх ролі у формуванні соціального (людського) капіталу, найважливішим компонентом якого виступають капітал здоров'я, освіти та культури. Соціальні послуги передбачають публічний характер прав особи, що претендує на отримання цих послуг, зумовлений тісними зв'язками між послугами та соціальними правами. Такі підходи до розуміння соціальних послуг демонструють їх головне спрямування - на ріст людського капіталу, забезпечення достойної якості життя та належних умов для відтворення. В даному контексті соціальні послуги (і сорера інституцій, що їх надають) відображають певний рівень розвитку суспільних цінностей, дотримання прав особи, стан демократичного управління в цілому.

Зважаючи на те, що в ході надання соціальних послуг відбувається водночас їх споживання і накопичення, витрати на розвиток сорери соціальних послуг носять інвестиційний характер, позаяк забезпечують накопичення людського капіталу. Усе вищезазначене пояснює високий ступінь державної (суспільної, громадської) участі в процесі надання соціальних послуг, а також необхідність широкого запровадження ідеї соціального замовлення. На підтвердження останньої тези свідчить наведене у новому Законі України «Про соціальні послуги» (№ 2671-VIII) визначення поняття соціального замовлення як засобу «регулювання діяльності у системі надання соціальних послуг шляхом залучення на договірній основі надавачів соціальних послуг для задоволення потреб осіб/сімей у соціальних послугах відповідно до результатів визначення потреб населення адміністративно-територіальної одиниці/територіальної громади у соціальних послугах» (ст. 1, п. 16).

Безперервний процес формування нових потреб особистості призводить до розвитку нових різновидів соціальних послуг та вдосконалення та/або підвищення якості, зміни змісту існуючих, а також пояснюють їх непересічну соціальну цінність.

2. Важливо розрізняти дві групи понять, що позначають соціальні послуги: 1) соціальні послуги, що надаються для всіх членів суспільства в інтересах розвитку самого суспільства (як складова сорери послуг); 2) соціальні послуги окремим (соціально незахищеним) прошаркам населення 3 метою соціальної допомоги і підтримки способу життя відповідно до соціальних стандартів.

В цьому контексті соціальні послуги розглядаються як в широкому (послуги, котрі мають на меті задоволення будь-яких соціальних потреб суспільства), так і у вузькому розумінні (послуги, які надаються соціальними працівниками і пов'язані з вирішенням скрутної життєвої ситуації особи, їі соціальним захистом). У широкому розумінні соціальні послуги реалізуються у соціальній сорері в цілому завдяки впровадженню соціальної політики держави. Вузький контекст передбачає, що послуги спрямовані на конкретних (закріплених законодавчо) отримувачів і їх потреби, з метою покращання чи відновлення їх життєдіяльності, соціальної адаптації. В такому розумінні соціальні послуги виступають як складова соціального захисту.

Обидві групи соціальних послуг відрізняються за економічною природою та способом впливу на рівень добробуту суспільства. Зауважимо, що у вступній частині нового Закону «Про 
соціальні послуги» (№ 2671-VIII) йдеться про те, що цей Закон визначає основні організаційні та правові засади надання соціальних послуг, спрямованих на профілактику складних життєвих обставин, подолання або мінімізацію їх негативних наслідків, особам/сім'ям, які перебувають у складних життєвих обставинах. Тобто йдеться про соціальні послуги у вузькому сенсі.

3. Соціальні послуги як нематеріальний товар, зорієнтований на соціальні ефекти з позиції як замовника (держави, територіальної громади, групи, особи), так і споживача.

В умовах ринкової економіки соціальну послугу трактують як продукт, що об'єктивно фрормується та розвивається на ринку послуг. Соціальна послуга розглядається як товар особливого виду, особлива споживча вартість процесу праці, виражена в корисному ефекті, що задовольняє потреби індивіда, виробництва та суспільства, має споживчу вартість і вартість, результат якої може мати матеріальну і нематеріальну форми. Відтак, соціальна послуга має економічну цінність, що робить її вірогідним об'єктом комерційної діяльності. В даному контексті ми можемо говорити про наявність (та/або можливість розвитку) сфери платних і безоплатних послуг. Сфера платних соціальних послуг фрормується і фрунціонує на засадах купівлі-продажу послуг як результату певної виробничогосподарської діяльності. Виробником послуг може виступати суб'єкт будь-якої форми власності. Сфера ж безоплатних послуг формується і функціонує за рахунок державного бюджету, внаслідок чого безоплатність послуг має відносний характер. Співвідношення між обсягами платних і безоплатних соціальних послуг населенню регулюється законодавством.

3 іншого боку, важливо враховувати, що соціальні послуги мають самостійну змістовну економічну цінність, здатну здійснювати суттєвий вплив на економічний ріст, соціально-економічний розвиток країни та задовольняти зростаючі потреби населення. Для держави та її інституцій важливо чітко знати, якими $€$ реальні витрати на здійснення соціальних послуг, скільки вони коштують, щоб грамотно бюджету вати їх надання. Дія ринку соціальних послуг визначається його специфічними властивостями та суспільною значимістю.

4. Соціальні послуги як (переважно) професійні дії, активна діяльність, спрямована на покращання умов життя людей.

Розгляд надання соціальних послуг в категоріях діяльності визначає цілі (як прогнозовані результати), мотиви і складові (предметний зміст; навики, операції, функції) даного процесу і носить переважно соціально-психологічний характер. Стосовно цілей - то у найбільш загальному вигляді їх зміст зводиться до задоволення певних потреб людей і отримання соціально корисного ефекту. Основною метою надання соціальних послуг є зміна життєвої ситуації клієнта (чи групи), в результаті чого відбувається покращання якості його (їх) життя. Варто відмітити, що ці зміни можуть досягатися різними шляхами: від елементарного отримання послуг (коли працівник тимчасово та/або одноразово задовольняє потребу клієнта), через формування одночасно з наданням послуг власних умінь та навичок у клієнта, спонукання його до дій по подальшому вирішенню проблем самостійно, до наснаження, формування нового ставлення до власної скрутної ситуації, опанування новим досвідом щодо її покращання.

Мотиви надання соціальних послуг переважно мають гуманістичне спрямування та мають розглядатися у двох площинах: мотивація працівника та мотивація клієнта. Мотивація фрахівця, який надає соціальні послуги, зумовлює перш за все якість наданого обслуговування, впливає на характер побудови взаємин із клієнтом, дозволяє запобігати професійним деформаціям спеціалістів і визначає дієвість самого процесу. 3 іншого боку, мотивація клієнтів також значно впливає на надання соціальних послуг: якщо клієнт свідомий того, що допомога у вигляді послуг надається йому для покращення його ситуації і він навчається у подальшому самостійно вирішувати власні проблеми, або, принаймні, прагне цього, то така соціальна допомога $€$ набагато дієвішою та ефективнішою. В разі, коли мотивація клієнта включає лише споживацькі наміри, то і соціальні працівники, відчуваючи таке ставлення, не налаштовані на ефективну взаємодію, і можуть здійснювати обслуговування не на належному рівні.

Щодо структури діяльності, то соціальні послуги можуть бути охарактеризовані як певні соціальні технології, що вимагають від надавача сформованих сенсорних, моторних, вольових та розумових навичок і дій. Способи дій надавачів визначаються з одного боку, відповідними посадовими інструкціями, а з іншого, - методами, підбір і розробка яких залежить від конкретної ситуації клієнта та професійності самого працівника. Потрібно пам'ятати, що соціальна послуга також має відповідати цілям наснаження.

Соціальним послугам як виду діяльності, притаманні також як загальні, так і специфічні риси. 
Зокрема, до загальних рис можна віднести: усвідомлений характер надання послуг, соціальна направленість та соціальна регламентованість цього виду діяльності, вмотивованість і цілеспрямованість, перетворюючий характер (наприклад, життєвої ситуації клієнта) та ін. Серед специфічних особливостей надання соціальних послуг можна назвати суб'єкт-суб'єктний характер взаємодії в процесі здійснення послуг. Йдеться про те, що клієнт (чи група клієнтів) виступають не лише як об'єкти, на які спрямовується активність соціального працівника, але і самі можуть впливати на надавача послуг, на свою ситуацію, бути залученими до процесу «вироблення» послуг, тобто, теж виступати суб'єктами діяльності. Специфічними особливостями соціальних послуг як діяльності є й те, що вони надаються відповідно до запиту і спрямовані на задоволення певних потреб клієнтів, а ключовим, центральним засобом праці в ході надання соціальних послуг виступає спілкування.

I, нарешті, не можна надати соціальну послугу шляхом бездіяльності чи утримання від певних видів дії. Тому соціальні послуги розглядають як діяльність певного виду, а, отже, вони передбачають певний рівень професійності надавачів, що, відповідно висуває вимоги до їх професійної кваліфікації. А, зважаючи на те, що сфера соціальних послуг є сукупністю багатьох видів діяльності, наслідком цього є велика різноманітність видів послуг.

Таким чином, основними функціями надання соціальних послуг як діяльності є: підтримка та покращання якості життя людей, які перебувають у скрутних життєвих обставинах; допомога у задоволенні потреб особи; сприяння соціалізації та ресоціалізації особистості, ії наснаження; профілактика негараздів, які можуть розвиватися як на рівні суспільства, так і на рівні групи чи конкретної особи та ін. Перелік функцій може змінюватися в залежності від виду наданих послуг та конкретних цілей, які ставляться в кожному випадку взаємодії з клієнтом.

Продуктом праці при наданні соціальних послуг, на наш погляд, виступає сама послуга. Причому, важливо відмітити, що дієвість її перш за все визначатиметься досягненням змін у ситуації клієнта, або ж опануванням ним новим позитивним (з точки зору вирішення проблематики) досвідом. Не меншої значимості в цьому аспекті набуває і якість послуги, точніше, можливість її оцінювання. 3 цією метою необхідно розробляти та впроваджувати стандарти надання послуг по кожному з їх видів. Дотримання стандарту і дасть змогу зрозуміти, наскільки якісними та доречними (такими, що відповідають запитам) є надані послуги.

При оцінці соціальних послуг як діяльності важливим $€$ також віднаходження відповіді на питання про те, чи використовуються достатні і належним чином ресурси, чи здійснюється діяльність відповідно до розробленого бюджету, складеного робочого плану та графіку тощо.

5. Соціальні послуги як результат соціально корисної діяльності передбачають отримання позитивного інституційно забезпеченого соціального ефекту.

В такому контексті нам імпонує визначення соціальних послуг як дій, що «в максимально можливій мірі допомагають запобігати, зменшувати та вирішувати соціальну залежність громадян з метою підвищення їх можливостей вести повноцінне та гідне життя та бути повним учасником суспільного життя, брати участь та бути активним у соціальному середовищі, де вони живуть» [10, с. 73]. Інакше кажучи, в результаті надання/отримання соціальних послуг людина отримує більше шансів інтегруватися в суспільство, отримати менш залежний (функціонально обмежений) статус, поліпшити умови життя та добробут. Тобто в означеному вище аспекті соціальні послуги виступають як важливий чинник підвищення рівня якості життя особи/групи, її об'єктивного та суб'єктивного благополуччя.

Результатом соціальних послуг має стати і мобілізація ресурсу особистості, групи, громади, та і самі послуги, їх надавання та отримання можуть розглядатися як важливий соціальний ресурс. Дійсно, в результаті надання/отримання соціальних послуг відбуваються якісні зміни об'єкта впливу. Причому, результат соціальних послуг передбачає і зміну стану (становища, статусу) клієнта (матеріального, соціально-психологічного тощо), його скрутної життєвої ситуації. Це також може бути і набутий ним досвід, генеровані в процесі обслуговування емоції, наснаження як життєва стратегія, що уможливлює досягнення особистістю та групою позитивних змін в життєвих ситуаціях різної складності. Важливо, щоб результат відповідав реальним потребам і прагненням індивіда, сприяв його розвитку, з одного боку, а з іншого, задовольняв вимогам стандартів із надання послуг.

Саме в аспекті оцінки результативності соціальних послуг набуває особливого значення світовий досвід регулювання надання соціальних послуг, що базується на системі «вимірювання 
діяльності» (performance measurement). Зазначена система використовується для оцінки дієвості соціальних проектів, а також визначення їх результативності та ефективності в процесі надання соціальних послуг. Вимірювання ж досягнутих результатів (results measurement) - дає змогу оцінити, чи результати, яких досягнуто, відповідають запланованим.

На підтвердження тези про важливість оцінки результату соціальних послуг, у новому Законі «Про соціальні послуги» (ст. 17) представлено стислу характеристику державного стандарту соціальних послуг, в якому: 1) встановлюються вимоги щодо забезпечення необхідного рівня доступності соціальних послуг, зокрема на кожному етапі їх надання; 2) визначаються зміст та обсяг, норми і нормативи, умови та порядок надання соціальних послуг, показники їх якості. Відомо, що наразі в Україні продовжується діяльність над розробкою державних стандартів із надання соціальних послуг, зокрема, інноваційних.

Таким чином, логіка аналізу дефрініції «соціальні послуги» може будуватися в напрямку пошуку відповідей на наступні запитання:

1) Яка мета надання соціальних послуг?

2) Хто надає послуги, за яких умов?

3) На кого/що направлена послуга?

4) Який зміст діяльності, що характеризує конкретну послугу?

5) Який результат прагнуть отримати від соціальної послуги та як його адекватно оцінити?

Також дуже важливим є врахування деяких соціально-психологічних аспектів процесу взаємодії в ході надання/отримання соціальних послуг. Йдеться про те, що клієнт (отримувач соціальних послуг) $€$ особистістю, яка перебуває у скрутних життєвих обставинах. Він має певні очікування та установки як стосовно послуг, так і по відношенню до самого соціального працівника як окремої особистості чи як представника держави/громади. В ході надання соціальних послуг відбувається взаємодія отримувача та надавача, яка обов'язково передбачає певний вплив одне на одного. В ідеалі цей вплив по відношенню до клієнта повинен призвести до його наснаження, отримання нового досвіду, зміни цінностей, поведінки, мобілізації потенціалу, подолання проблематики тощо. А стосовно соціального працівника, за негативних обставин, даний вплив може відобразитися у вигляді професійного вигорання, деформації, виснаження і т.д., що зумовлює необхідність постійної роботи над вдосконаленням професійності тих, хто надає соціальні послуги.

Отже, соціальні послуги в контексті теорії соціальної роботи - це нематеріальний продукт суспільно-корисної діяльності, процес і результат нормативно регламентованої професійної взаємодії між надавачем та отримувачем, спрямований на задоволення потреб і досягнення позитивного соціального ефекту у вигляді профілактики/долання/ мінімізації наслідків скрутної життєвої ситуації отримувача, мобілізації його ресурсного потенціалу, покращення якості життя.

Висновки. Основні проблеми концептуалізації соціальних послуг, на нашу думку, зумовлені багатоаспектністю їх розуміння та використання у різних наукових дискурсах. Ми свідомі того, що в межах однієї публікації дуже важко ґрунтовно висвітлити усе різноманіття наявних підходів до визначення категорії «соціальні послуги» в системі координат соціальної роботи. Поза нашою увагою залишилися проблеми, пов'язані з критеріями та класифікацією соціальних послуг, особливостями організації і функціонування системи соціальних послуг на різних рівнях, чинниками, що впливають на формування запиту на соціальні послуги, принципами та засадами розвитку соціальних послуг на рівні громад тощо. Тим не менше, ми спробували зосередитися на ключових аспектах, розуміння яких, на наш погляд, дозволить просунутися у вирішенні проблем концептуалізації означеної категорії.

\section{Література}

1. Закон України "Про соціальні послуги" [Електронний ресурс] // Відомості Верховної Ради України (ВВР). - № 2671-VIII. - 17.01.2019. - Режим доступу: https://zakon.rada.gov.ua/laws/show/2671-19.

2. G. Lynn Shostack How to Design a Service [Electronic resource]. European Journal of Marketing, - 1982. - Vol. 16, Issue: 1. - P. 49-63. - Access mode: https://doi.org/10.1108/EUM0000000004799.

3. T. Rieder, A. Schott-Winterer, A. Woller Soziale Dienstleistungen und Wohlfahrtsstaat. Vergleichende Analysen zur Beschftigung im Arbeitsmarktsegment `Soziale Dienstleistungen` in der BRD und den USA. / Soziale Welt. - 1988. - № 39 (3). - C. 292-314.

4. Fiona Mitchell, Ian F. Shaw, Neil Lunt. Practitioner Research in Social Services: a Literature Review.- 2012. - University of York. -49 p.

5. Alfonso Lara Montero. Evidence in public social services [Electronic resource] - 2015. - Access mode: https://www.esneu.org/sites/default/files/publications/Evidence_in_public_social_services.pdf. 
6. Апопій, В. В. Організація і технологія надання послуг: навч.посіб ./ В. В. Апопій, І. І. Олексин, Н. О. Шутовська, Т. В. Футало; за заг.ред. В.В. Апопія. - К. : ВЦ «Академія», 2006. - 312 с.

7. Інноваційні моделі соціальних послуг: Проекти Українського фонду соціальних інвестицій. [авт. кол. Л. В. Бондарчук, Л. П. Дума, Н. В. Кабеченко [та ін.]; за редакцією Н. М. Шкуратової]. - К. : ТОВ «ЛДЛ», 2007. - 320 с.

8. Кривоконь, Н.І.Соціально-психологічне забезпечення соціальної роботи : монографія / Н. І. Кривоконь. - Харків : видавництво ФОП Олійник, 2011. - 480 с.

9. Мещан, І. В. Соціальне обслуговування як складова соціального захисту населення: соціолого - управлінський аспект / І. В. Мещан // Науково-теоретичний альманах «Грані». - 2015. - № 8 (124) . - С. 71 -76.

10. Крупа, С. Якість соціальних послуг. Тренінг для соціальних працівників / Крупа С. [та ін.] - Братислава-Київ : Грант "Open Society Foundetion", 2009. - 64 c.

\section{References}

1. Zakon Ukrainy "Pro sotsialni posluhy": vid 17.01.2019 № 2671-VIII [Law of Ukraine "On Social Services" from 17.01.2019 № 2671-VIII]. zakon.rada.gov.ua. Retrieved from https://zakon.rada.gov.ua/laws/show/2671-19 [in Ukrainian].

2. Lynn, G. (1982). Shostack How to Design a Service. European Journal of Marketing, 16(1), 49-63. Retrieved from https://doi.org/10.1108/EUM0000000004799 [in English].

3. T. Rieder, A., Schott-Winterer, A. (1988). Woller Soziale Dienstleistungen und Wohlfahrtsstaat. Vergleichende Analysen zur Beschftigung im Arbeitsmarktsegment `Soziale Dienstleistungen` in der BRD und den USA. Soziale Welt, 39(3), 292-314 [in German].

4. Mitchell, F., Shaw, I. F., Lunt, N. (2012). Practitioner Research in Social Services: a Literature Review. University of York [in English].

5. Montero, A. L. (2015). Evidence in public social services. Retrieved from https://www.esn-eu.org/sites /default/files/publications/Evidence_in_public_social_services.pdf [in English].

6. Apopii ,V. V., Oleksyn, I. I., Shutovska, N. O., Futalo, T. V. (2006). Orhanizatsiia i tekhnolohiia nadannia posluh [Organization and technology of providing services]. Kyiv: VTs «Akademiia» [in Ukrainian].

7. Bondarchuk, L. V., Duma, L. P., Kabechenko, N. V., et. al. (2007). Innovatsiini modeli sotsialnykh posluh: Proekty Ukrainskoho fondu sotsialnykh investytsii [Innovative models of social services: Projects of the Ukrainian Fund for Social Investments]. N. M. Shkuratova (Eds.). Kyiv: TOV «LDL» [in Ukrainian].

8. Kryvokon, N. I. (2011). Sotsialno-psykholohichne zabezpechennia sotsialnoi roboty [Social and psychological support of social work]. Kharkiv : vydavnytstvo FOP Oliinyk [in Ukrainian].

9. Meshchan, I. V. (2015). Sotsialne obsluhovuvannia yak skladova sotsialnoho zakhystu naselennia: sotsioloho upravlinskyi aspekt [Social service as an integral part of social protection of the population: sociological and managerial aspect]. Naukovo-teoretychnyi almanakh «Hrani» - Scientific and theoretical almanac "Grani", 8(124), 71-76 [in Ukrainian].

10. Krupa, S., et. al. (2009). Yakist sotsialnykhi posluh. Treninh dlia sotsialnykh pratsivnykiv [Quality of social services. Training for social workers]. Bratyslava-Kyiv: Hrant "Open Society Foundetion" [in Ukrainian].

Бібліографічний опис для цитування:

Надійшла 19.06.2019

Кривоконь, Н. І. Дефрініція категорії «соціальні послуги»: проблеми концептуалізації / Н. І. Кривоконь // Проблеми соціальної роботи: філософрія, психологія, соціологія. - 2019. - № 1 (13). - С. 37-45. 